\title{
Mechanical Properties of Geopolymer Concrete Exposed to Combustion
}

\author{
Annisa Rahmadina ${ }^{1,2, *}$, and Januarti Jaya Ekaputri ${ }^{1,2,{ }^{*}}$ \\ ${ }^{1}$ Institut Teknologi Sepuluh Nopember, Civil Engineering Department, 60111 Surabaya, Indonesia \\ ${ }^{2}$ Konsorsium Riset Geopolimer Indonesia, Concrete and Building Material Laboratory Institut \\ Teknologi Sepuluh Nopember, 60111 Surabaya, Indonesia
}

\begin{abstract}
This paper presents the change of material properties, such as decreasing of the compressive strength, splitting tensile strength, and porosity. The main objective of this paper is to analyze the mechanical properties of fly ash-based geopolymer concrete after being exposed to high temperature. The $28^{\text {th }}$-day test specimens were burned for one hour at specified temperature variation of $200^{\circ} \mathrm{C}, 400^{\circ} \mathrm{C}, 600^{\circ} \mathrm{C}$, and $800^{\circ} \mathrm{C}$. Ordinary Portland Cement (OPC) concrete was used as a comparison. After burning at $400^{\circ} \mathrm{C}$, the compressive strength of geopolymer concrete was surprisingly increased up to $27 \%$ of its normal strength. On the other hand, the compressive strength of OPC concrete decreased $67 \%$ from its normal strength. The splitting tensile strength of geopolymer concrete also decreased at the range of $50-70 \%$. The porosity of concrete has a sufficient effect to compressive strength and splitting strength. X-Ray Diffraction (XRD) test of geopolymer concrete at temperature $400^{\circ} \mathrm{C}$ until $600^{\circ} \mathrm{C}$ showed some minerals change. Geopolymer concrete is proved to have better fire resistance compares to Portland Cement Concrete.
\end{abstract}

\section{Introduction}

Fires that lead to the increasing of significant temperature have an impact to the changes of properties of concrete such as mechanical, physical and chemical properties [1]. The high temperature affects the characteristics of concrete such as the decreased at strength, peeling surface on concrete, and the occurrence of cracks.

Geopolymer concrete is known as concrete that uses non-Portland binder in the mixture. As a substitute for cement, Material that has high silica and alumina content such as fly ash is chosen. Fly ash needs alkali activator to create a binder. Commonly used alkali activator is the mixture of sodium hydroxide $8 \mathrm{M}$ to $14 \mathrm{M}$ and sodium silicate with the ratio of 0.4 to $2.5[2]$.

Geopolymer concrete posses higher resistance to fire than Ordinary Portland Cement concrete [3]. Geopolymer concrete has little shrinkage. Kong et al. [4] stated that the use of superplasticizer had no significant affect on the performance of geopolymer concrete, especially after being exposed to a high temperature. The Addition of superplasticizer is only to improve the workability of geopolymer concrete. Pan et al. [5] stated that at high

*Corresponding author: annisarahma.jbr@gmail.com and januartije@gmail.com 
temperatures chemical properties of geopolymer were more stable, while the OPC concrete was dehydrated. The loss of structural water indicates that Portland Cement-based concrete hydrates and then disintegrate at the increased temperature.

The different temperatures have significant impact to the shrinkage of geopolymer concrete. Geopolymer concrete samples that burned at temperatures below $200^{\circ} \mathrm{C}$ showed shrinkage at about $6 \%$. At $250^{\circ} \mathrm{C}$, the shrinkage decreased to $2 \%$. The conditions of geopolymer concrete tend to be stable at temperature $250^{\circ} \mathrm{C}$ to $800^{\circ} \mathrm{Cwhile}$ the heating process to $900^{\circ} \mathrm{C}$ resulted in the greater shrinkage of geopolymer [6].

In the process occurred a cycle of heating and cooling, resulting in a change of phase in the complex physical and chemical basis, it affected the quality of concrete structures and leading to brittle concrete [7]. The increase in temperatures led to the decrease of the compressive strength of geopolymer. The decreasing of the strength was caused by dehydration and dehydroxylation processes at the temperature $400^{\circ} \mathrm{C}$ to $600^{\circ} \mathrm{C}[7,8]$. While heating from room temperature to $800^{\circ} \mathrm{C}$, the $\mathrm{OPC}$ concrete greatly experienced cracking and spalling [5]. The OPC concrete showed at about $46.5 \%$ loss in compressive strength at $600^{\circ} \mathrm{C}$. The significant loss of strength in $\mathrm{OPC}$ concrete after $400^{\circ} \mathrm{C}$ was related to the dissociation of calcium hydroxide [9]. At the same temperature, geopolymer concrete samples were more stable than the OPC concrete. Physically, geopolymer concrete is resistant to high temperature up to $1000^{\circ} \mathrm{C}$. Cracks in geopolymer concrete were less than in the Portland Cement-based concrete [10]

\section{Experimental Program}

\subsection{Material and mix design}

Class F fly ash was used as the binder for geopolymer concrete. The chemical properties of fly ash are shown in Table 1 .

Table 1. Chemical composition of fly ash

\begin{tabular}{lccccccccccc}
\hline Chemical & $\mathrm{SiO}_{2}$ & $\mathrm{Al}_{2} \mathrm{O}_{3}$ & $\mathrm{Fe}_{2} \mathrm{O}_{3}$ & $\mathrm{TiO}_{2}$ & $\mathrm{CaO}$ & $\mathrm{MgO}$ & $\mathrm{Cr}_{2} \mathrm{O}_{3}$ & $\mathrm{~K}_{2} \mathrm{O}$ & $\mathrm{Na}_{2} \mathrm{O}$ & $\mathrm{SO}_{3}$ & $\mathrm{Mn}_{2} \mathrm{O}_{3}$ \\
\hline $\begin{array}{l}\text { Percentage } \\
\text { (wt.\%) }\end{array}$ & 48,47 & 26,05 & 12,54 & 0,92 & 5,18 & 2,77 & 0,02 & 1,66 & 0,47 & 1,05 & 0,19 \\
\hline
\end{tabular}

The alkaline liquid in the mixture of geopolymer contains sodium hydroxide of $8 \mathrm{M}$ and sodium silicate. Sodium silicate contains $\mathrm{Na}_{2} \mathrm{O}, \mathrm{SiO}_{2}$, and $\mathrm{H}_{2} \mathrm{O}$ by percentage of mass at around $18.5 \%, 36.4 \%$, and $45.1 \%$ respectively. Coarse aggregate and fine aggregates were used in saturated surface dry (SSD) condition. The maximum size of coarse aggregate was $20 \mathrm{~mm}$. All the aggregate requirements for concrete mix design satisfied ASTM C 33 [11].

The material proportion for geopolymer concrete per cubic meter is provided in Table 2. Ordinary Portland Cement (OPC) concrete was used as the control system. The mixing and casting procedures for geopolymer were similar to OPC concrete. All initial strengths of concrete were designed for $56 \mathrm{MPa}$ at 28 days.

Table 2. Mixture proportion of concrete per $\mathrm{m}^{3}$

\begin{tabular}{|l|c|c|c|c|c|c|c|c|}
\hline \multicolumn{7}{|c|}{ Materials (kg) } \\
\hline Specimen & $\begin{array}{c}\text { Fly } \\
\text { ash }\end{array}$ & Cement & $\begin{array}{c}\text { Coarse } \\
\text { agregate }\end{array}$ & $\begin{array}{c}\text { Fine } \\
\text { agregate }\end{array}$ & $\mathrm{Na}_{2} \mathrm{SiO}_{3}$ & $\mathrm{NaOH}$ & Water & $\begin{array}{c}\mathrm{SP} \\
2 \%\end{array}$ \\
\hline Geopolymer & 390 & - & 1080 & 720 & 140 & 70 & - & 7.8 \\
\hline OPC & - & 539.47 & 1014.03 & 621.50 & - & - & 205 & - \\
\hline
\end{tabular}




\subsection{Casting and curing of geopolymer concrete specimens}

Geopolymer and Ordinary Portland Cement (OPC) concrete were cast into cylinder molds with dimension of $100 \mathrm{~mm}$ in diameter and $200 \mathrm{~mm}$ in height. The variations of geopolymer, and OPC concrete were shown in Table 3. One day-after casting, geopolymer and OPC concrete were cured in water (wet curing) for 28 days.

Table 3. Hardened concrete specimens test mixture proportion

\begin{tabular}{|c|c|c|l|c|}
\hline Specimen & $\begin{array}{c}\text { Compressive Strength } \\
\text { (Age 28-days) }\end{array}$ & $\begin{array}{c}\text { Sample } \\
\text { size }\end{array}$ & Variation & $\begin{array}{c}\text { No. of Samples } \\
\text { per Variation }\end{array}$ \\
\hline $\begin{array}{c}\text { Geopolymer } \\
\text { Concrete }\end{array}$ & $56.4 \mathrm{MPa}$ & $\begin{array}{c}100 \mathrm{~mm} \Phi \\
\text { x 200mm } \\
\text { cylinder }\end{array}$ & $\begin{array}{l}\text { GCN; GC200; GC400; } \\
\text { GC600; GC800 }\end{array}$ & $\begin{array}{l}\text { OPCN; OPC200; OPC400; } \\
\text { OPC600; OPC800 }\end{array}$ \\
\hline $\begin{array}{c}\text { OPC } \\
\text { Concrete }\end{array}$ & $56.4 \mathrm{MPa}$ & $3 / \mathrm{mix}$ & $3 / \mathrm{mix}$ \\
\hline
\end{tabular}

\subsection{Heating methods}

At the ages of 28 days, the specimens were heated in the furnace at $200^{\circ} \mathrm{C}, 400^{\circ} \mathrm{C}, 600^{\circ} \mathrm{C}$, and $800^{\circ} \mathrm{C}$ temperatures for one hour. The specimens were heated to a maximum furnace temperature of $800^{\circ} \mathrm{C}$ and burnt up to 19.5 hours. Detail of the duration of burning process was presented in Figure 1.

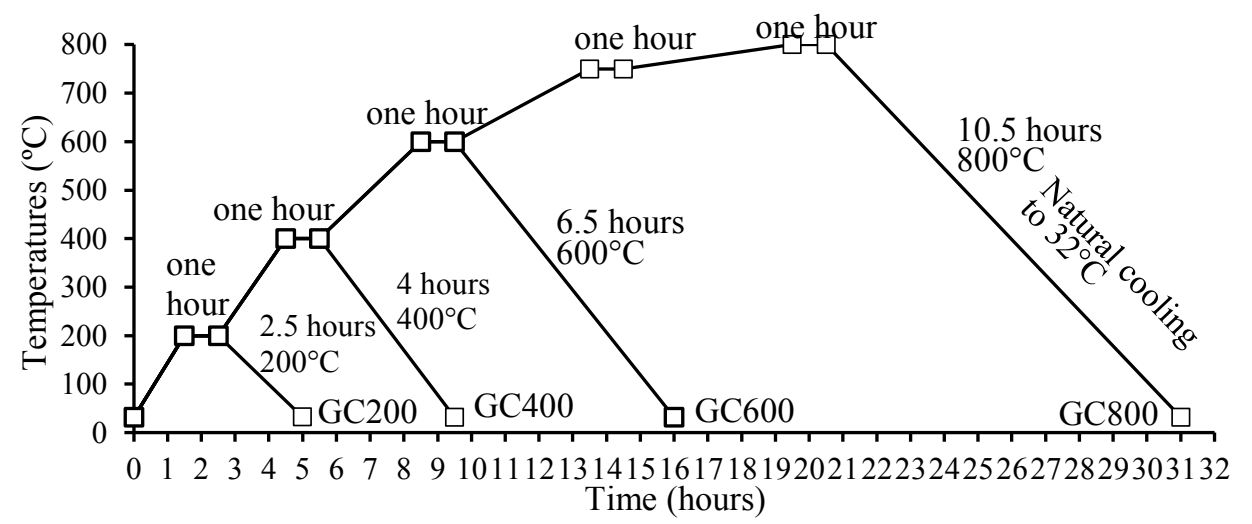

Fig. 1. Elevated temperature-history for specimens exposed to fire.

\subsection{Test procedure of geopolymer concrete}

After combustion process, all of the specimens were cooled off to normal temperature. The specimens were tested for the compressive strength and splitting tensile strength according to ASTM C 39 and ASTM C $496[12,13]$. The compressive strength of heated specimens after exposure to the fire then compared to the strength of the unheated specimen. Some fractions of a geopolymer concrete specimen were used for porosity test. X-Ray Diffraction test was also conducted to determine the mineral contents in geopolymer concrete after the combustion. 

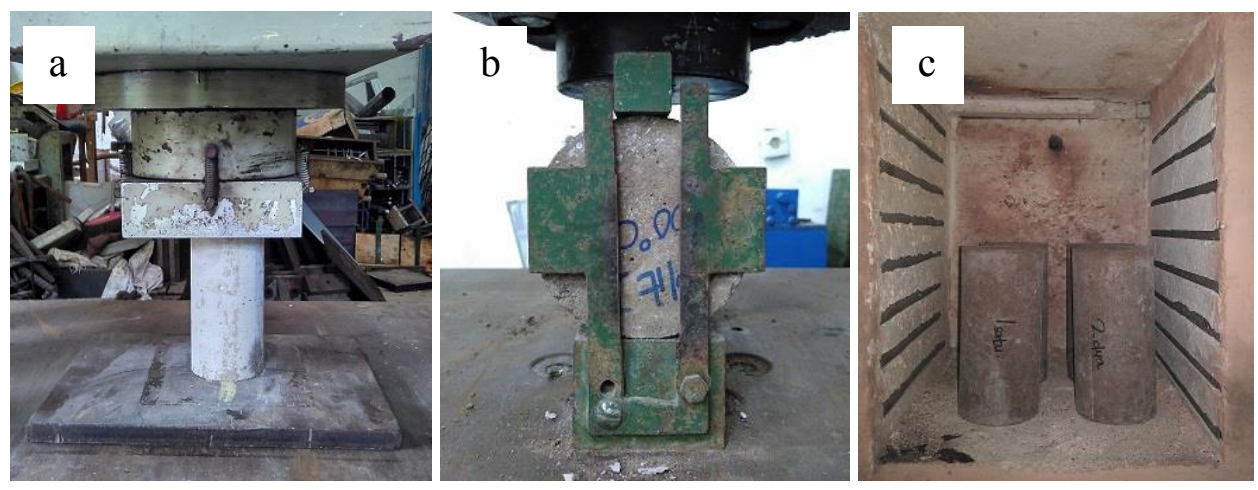

Fig. 2. a. Compressive strength test, b. Splitting tensile test, c. After burning in the furnace.

\section{Result and discussion}

\subsection{Compressive strength of the specimens}

The result of the compressive strength of concrete before and after exposure to the fire was shown in Figure 3. At the temperature of $400^{\circ} \mathrm{C}$, compressive strength of geopolymer concrete was $14.67 \%$ higher compared to the compressive strength of geopolymer at the normal temperature. Geopolymer concrete at $800^{\circ} \mathrm{C}$ temperatures tends to have a lower compressive strength compared to the compressive strength at the other temperatures. The higher temperatures result in the decreasing of the compressive strength of geopolymer concrete [7], but at specific temperature, the strength of geopolymer increased. It was shown that the strength of the geopolymer concrete was influenced by dehydration and dehydroxylation $[8,9]$.

The compressive strength of OPC concrete was decreased as the increased in temperatures. At the temperature from $600^{\circ} \mathrm{C}$ to $800^{\circ} \mathrm{C}$, the compressive strength of the OPC concrete was decreased significantly. The strength of OPC concretes were $30 \mathrm{MPa}$ and $19 \mathrm{MPa}$ at the temperature of $600^{\circ} \mathrm{C}$ and $800^{\circ} \mathrm{C}$. The strength of geopolymer concrete was $51 \mathrm{MPa}$ and $40 \mathrm{MPa}$ at the same temperature. It was shown that at elevated temperature, the strength of OPC concrete decreased significantly to $56 \%$ by its initial compressive strength. This was mainly due to the excessive build-up of vapor pressure that produces large cracks in the matrices of concrete [14].

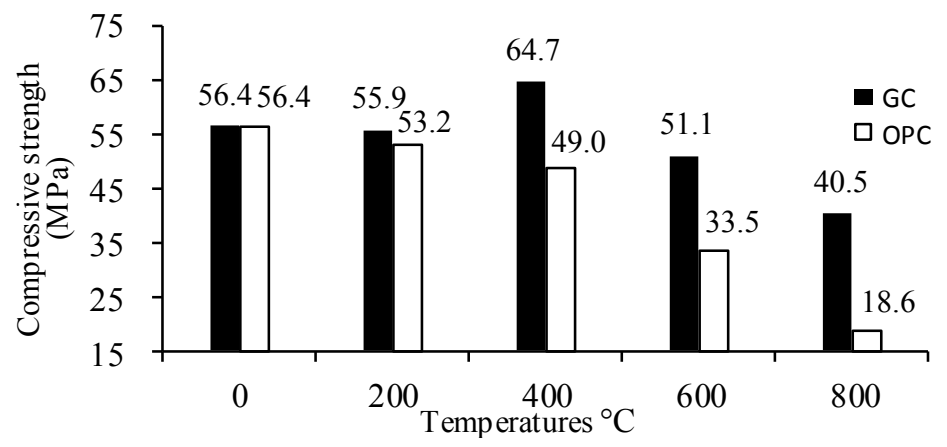

Fig. 3. Compressive strength of geopolymer and OPC concrete at elevated temperature. 


\subsection{Splitting of the geopolymer concrete}

The effects of temperature to the splitting strength of geopolymer concrete were presented in Figure 4. The lowest split strength showed by the specimens exposed to $800^{\circ} \mathrm{C}$ temperature. Pan [5] stated that the splitting strength of the geopolymer concrete decreases as the heating temperature increases. Figure 5 shows spalling occurs easily at elevated temperatures. Thermal stresses were believed to lead to force spalling of concrete. It is composed of entirely different binder properties [5].

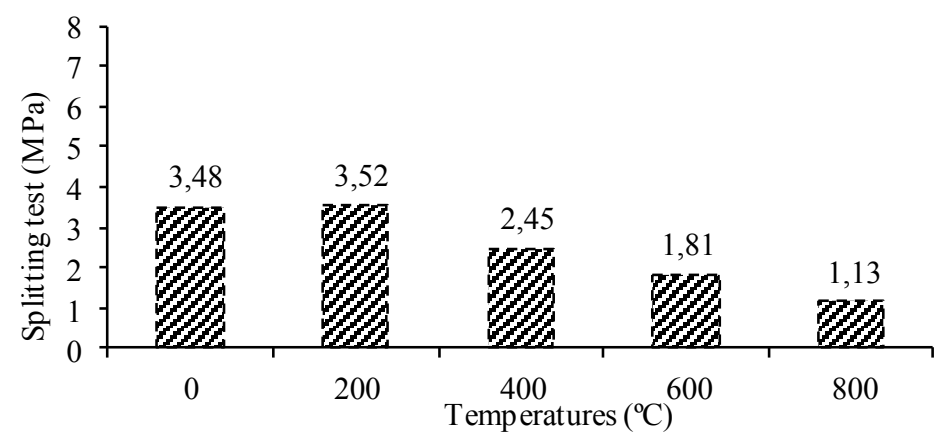

Fig. 4. The effect of elevated temperature to splitting test.

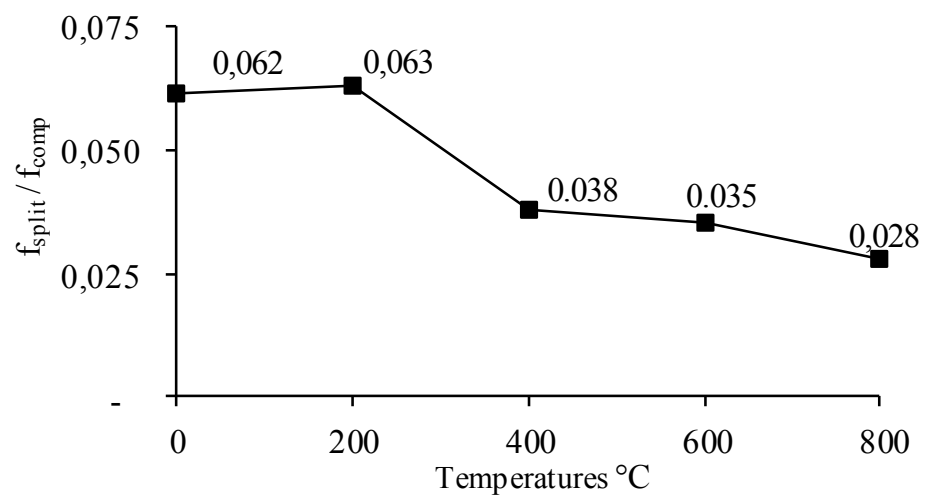

Fig. 5. Ratio of $\mathrm{f}_{\text {split }}$ to fompressive at different temperature.

\subsection{Porosity}

Porosity test shows the effect of pores on geopolymer concrete. The test results for the porosity were shown in Figure 6 . The highest porosity of geopolymer concrete after exposure to fire occur in GC800 by $19.6 \%$ where the unclosed porosity is $14.3 \%$. Meanwhile, the lowest porosity was found in geopolymer concrete GC400 by $15.8 \%$ where the open porosity is $6.3 \%$. The pore size after exposure to high temperatures was significantly decreased in fly ash-contained specimens [15]. Large porosity occurs when the water content is high. When the content becomes small then the small porosity occurs [16]. At $400^{\circ} \mathrm{C}$, compaction occurs due to mineral changes caused by hydroxylation process. According to Kong et al. [17] high temperature led to change in chemical structure and free dehydration occurs. It resulted in the internal damage of the concrete. 


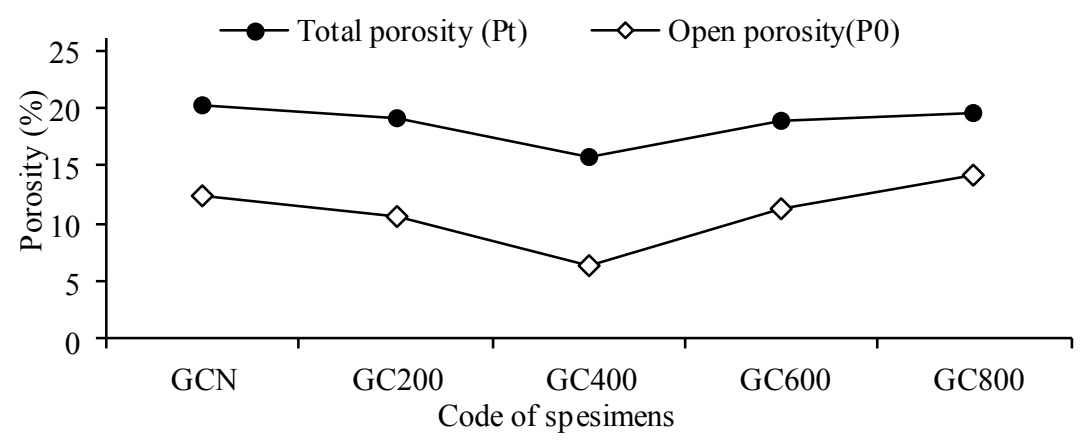

Fig. 6. Total and open porosity of geopolymer concrete

\subsection{Residual strength of geopolymer and OPC concrete}

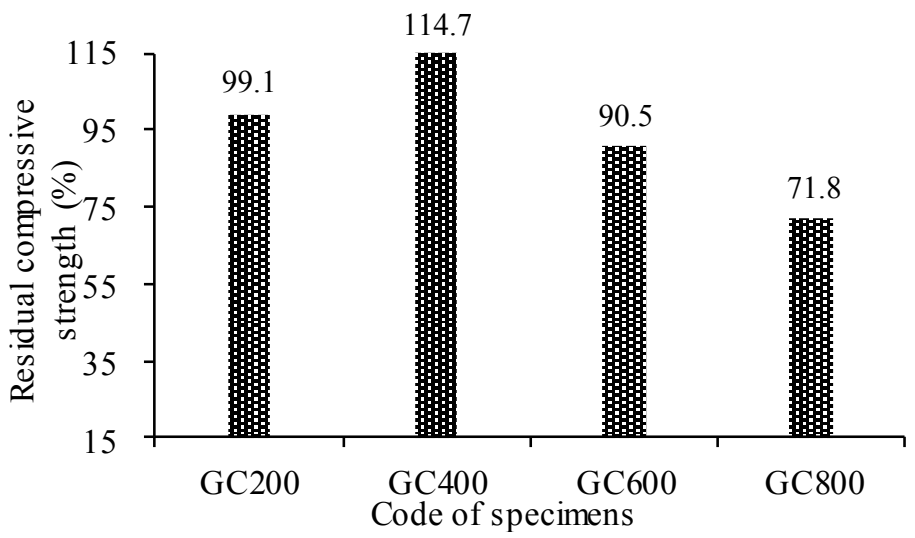

Fig. 7. Residual strength of geopolymer concrete

Figure 7 shows the percentage of residual compressive strength of specimens after exposed to fire to determine the resistance of concrete specimens at high temperatures. At temperature of $400^{\circ} \mathrm{C}$, residual strength of geopolymer concrete was increased to $14.7 \%$. At temperature of $250^{\circ} \mathrm{C}$ to $600^{\circ} \mathrm{C}$ geopolymer concrete experienced dehydroxylation and resulted to the decreased and increased compressive strength. These phenomenon caused by a cluster of hydroxyl are abundant [8]. The strength of geopolymer concrete decreased was caused by the differential expansion between aggregate and geopolymer. The geopolymer matrix experienced contraction at high-temperature [18]. 


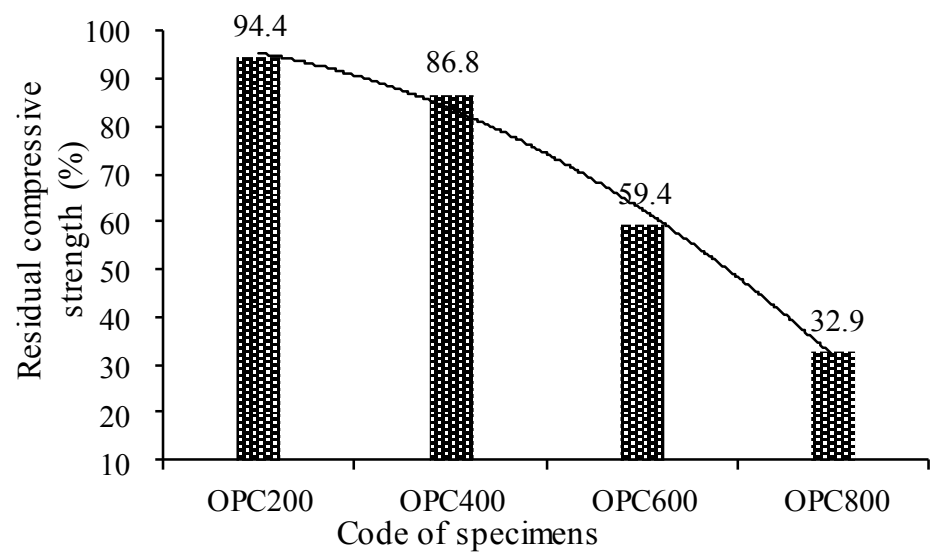

Fig. 8. Residual strength of OPC concrete

Along with the increased of firing temperature compressive strength was decreased. The compressive strength was decreased at the temperature of $400^{\circ} \mathrm{C}, 600^{\circ} \mathrm{C}, 800^{\circ} \mathrm{C}$, at about $48.98 \mathrm{MPa}, 33.53 \mathrm{MPa}$, and $18.53 \mathrm{MPa}$. Residual compressive strengths at each temperature were $86.8 \%, 59.4 \%$, and $32.9 \%$. The residual strengths of OPC concrete tend to decrease drastically at the temperature of $600^{\circ} \mathrm{C}$ to $800^{\circ} \mathrm{C}$ [9]

Figure 7 and figure 8 concluded that the residual strength of geopolymer concrete is higher than $\mathrm{OPC}$ concrete. At the maximum temperature of $800^{\circ} \mathrm{C}$, the residual strength of OPC concrete was less than $50 \%$. This showed the superior fire endurance ability of fly ash-based geopolymer concrete to the OPC concrete [10]

\subsection{Discoloration, spalling and cracking in surface of the geopolymer and OPC concrete}

The discoloration on the surface of the geopolymer and Ordinary Portland Cement concrete is shown in figure 9. From the observation of the physical condition before and after exposure to fire, at the normal condition, the color of OPC concrete was changed to be darker than OPC concrete after being burned. At temperature $200^{\circ} \mathrm{C}$, OPC concrete began to change its color and the color becomes brighter. The color changed due to the increase in temperature [9]. After the exposure to temperature $800^{\circ} \mathrm{C}$, the color appeared to change from grey to pink [19]. Moreover, at temperatures $800^{\circ} \mathrm{C}$ physical condition of OPC concrete showed a significant change. Crack occurs across the surface of concrete, and the edge of concrete was ruptured.

On the surface of concrete was appeared the limestone. Crack in concrete was caused by a concrete shrinkage process during the heating process [6]. It was the same as that proposed by Sarker et al. [10] after exposed to fire, in geopolymer concrete specimen was found smaller damaged (in this case crack) rather than OPC concrete specimen. After burnt at temperature of $800^{\circ} \mathrm{C}$ geopolymer, concrete experienced significant discoloration. 


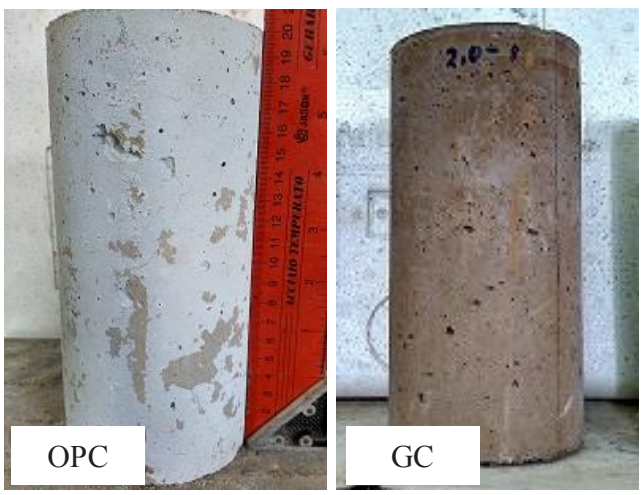

Fig. 9. Different color of OPC concrete and Geopolymer concrete after heating to fire at $800{ }^{\circ} \mathrm{C}$.
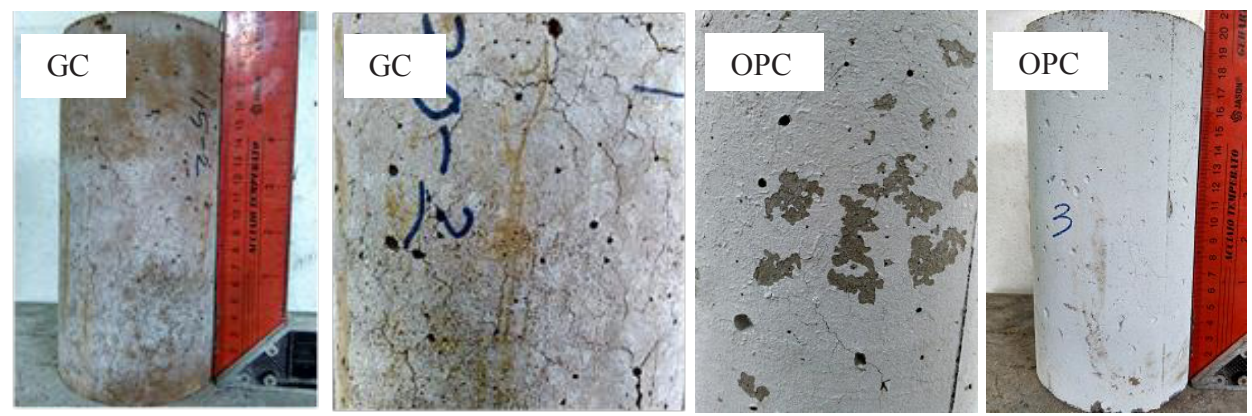

Fig. 10. Discoloration and cracking in surface of geopolymer and OPC concrete at temperature $800^{\circ} \mathrm{C}$.

Figure 10 shows cracking patterns across the surface of the concrete. Cracks in the concrete were caused by the shrinkage that occurred after the concrete burnt. Both geopolymer and OPC concrete exploded during fire exposure. At the identical elevated temperature, the result showed that the spalling of geopolymer concrete was less than OPC concrete. The spalling also showed the same result with the result observed by Pan et al. [5]. The geopolymer samples were slightly cracked on concrete surfaces after exposure to fire [19]. The matrix of geopolymer concrete was stable at the elevated temperature.

\subsection{X-Ray Diffraction analysis}

X-ray diffraction test was carried out to investigate the mineral change in geopolymer concrete during thermal exposure. Mineral changes were presented in Fig. 11.

Figure 11 presents the XRD results of a specimen before and after firing. At $400^{\circ} \mathrm{C}$, some minerals such as albite, quartz, rutile were increased significantly. The mineral in geopolymer concrete increased after exposured to high temperature. Quartz and albite were affected by temperatures. Albite is a crystal mineral. Due to the influence of temperature, albite structure was changed. However, the chemical element composition was remained (recrystallizes). At the time of exposure, the amount of albite increased due to the change of mineral from amorph to the crystal. Hematite in the region 35-2 $\theta$ appeared from the glassy phase of fly ash [19]. At the temperature of 400 to $600^{\circ} \mathrm{C}$, zeolites found in alkali-activated fly ash systems was relatively stable. It was characterized by the occurrence of minor dehydration [20]. 


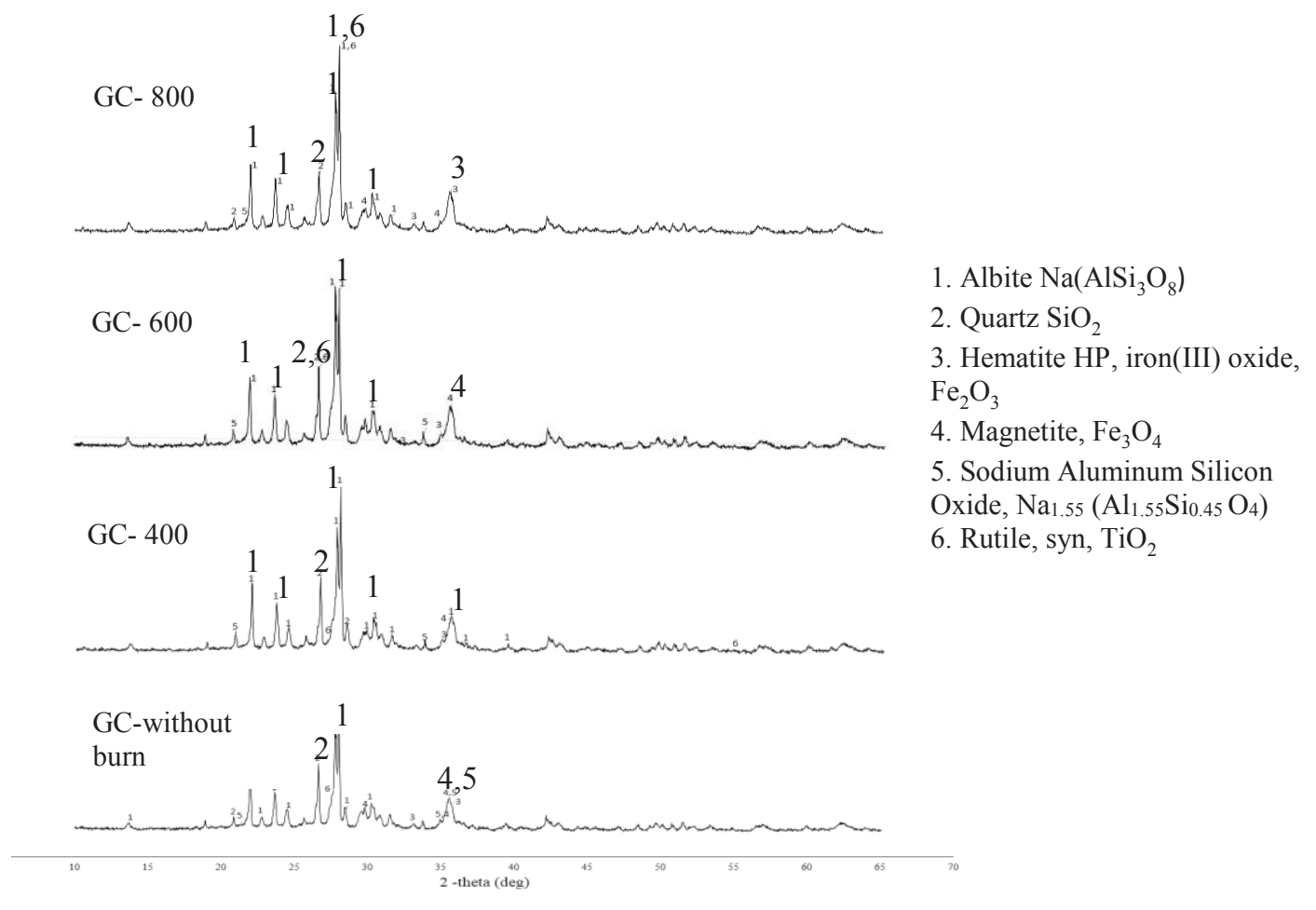

Fig. 11. XRF of geopolymer concrete

\section{Conclusions}

1. After geopolymer and OPC concrete was burned, both of the compressive strength decreased. But the compressive strength of geopolymer at the temperature of $400^{\circ} \mathrm{C}$ was increased by 14 to $18 \%$.

2. Geopolymer concrete has good fire resistance due to chemical bonds in geopolymer concrete. After exposed to fire, the amount of some minerals of geopolymer concrete increased at the temperature of $400^{\circ} \mathrm{C}-800^{\circ} \mathrm{C}$.

3. At some temperatures, the increase in compressive strength was indicated by the porosity test results. Compaction occurs at the temperature of $400^{\circ} \mathrm{C}$. X-Ray Diffraction test results indicated that some minerals changed. It was caused by dehydroxylation process.

4. Geopolymer concrete has more resistant to elevated temperatures compared to Ordinary Portland Cement (OPC) concrete. The relative residual strength for all geopolymer concrete were greater than $\mathrm{OPC}$ concrete after exposure to $200^{\circ} \mathrm{C}, 400^{\circ} \mathrm{C}$, $600^{\circ} \mathrm{C}$, and $800^{\circ} \mathrm{C}$.

5. At the elevated temperature, spalling easily occurred. Spalling occurs due to thermal pressure.

\section{References}

1. P.K. Sarker, S. Kelly and Z. Yao, Material and Design, 63, pp.584-592 (2014)

2. D. Hardjito, B.V. Rangan, "Research Report GC 1, Australia: Curtin University of Technology", (2005) 
3. F. Skvara, L. Kopecky, J. Nemecek, Z. Bittner, "Microstructure of geopolymer materials based on fly ash, Ceramics-Silikaty", (4), 208-215 (2006)

4. D.L.Y. Kong, J.G. Sanjayan, Cement and Concrete Research, 40, 334-339 (2010)

5. Z. Pan, J.G. Sanjayan, D.L.Y. Kong, Construction and Building Materials, 36, 365372 (2012)

6. Subaer, A.V. Riesen, “Advances in Geopolymer Science and Technology, J. Mater Sci.”, 42, 3117-3123 (2007)

7. O.A. Abdulkareem, M. Al Bakri, H. Kamarudin, I.K. Nizar, A.A. Saif, Construction and Building Materials, 50, pp. 377-387 (2014)

8. L. Vickers, V.A. Riessen, W.D. Rickard, Springer Briefs in Materials (2015)

9. F.U.A. Shaikh, V. Vimonsatit, Fire and Materials (2014)

10. P.K. Sarker, S. Mcbeth, Construction and Building Materials, 90, 91-98 (2015)

11. American Society for Testing and Materials, ASTM C 33 (2010)

12. American Society for Testing and Materials, ASTM C 39 (2013)

13. American Society for Testing and Materials, ASTM C 496 (2013)

14. I. Turkmen, M.B. Karakoc, F. Kantarci, M.M. Maras, R. Demirboga, Fire and Materials (2016)

15. R.Kh. Ibrahim, R. Hamid, M.R. Taha, Construction and Building Materials (2012)

16. H. Cheng, K.L. Lin, R. Chi, C.L. Hwang, T.W. Cheng, Y.M. Chang, Construction anf Building Materials, 88, 74-83 (2015)

17. D.L.Y Kong, J.G. Sanjayan, K.S. Crentsil, Cement and Concrete Research, 37, 15831589 (2007)

18. D.L.Y. Kong, J.G. Sanjayan, Cement and Concrete Composites, 30, 986-991 (2008)

19. A.M. Rasyad, S.R. Zeeden, Construction and Building Materials, 25, 3098-3107 (2011)

20. A.F. Jimenez, A.G. de la Torre, A. Palomo, G. Lopez-Olmo, M.M. Alonso, M.A.G. Aranda, Fuel, 85, 1960-1969 (2006) 